\title{
Pareto's Law As Structural Economic Synapse
}

\author{
Alexandru Trifu \\ University Petre Andrei of Iasi \\ alexandru.trifu@gmail.com
}

\begin{abstract}
Starting from the observations of Italian economist Vilfredo Pareto, in the early days of XX-th century, refering to personal income distribution, we are coming to understand that it is not enough heightens the wealth of a nations, so that collective welfare to increase. It requires that the wealth created to be equitably distributed and not equally. Today, the famous Paretian Principle 80/20 demonstrates that we must wisely use the resources (i.e. 20\%), enhance productivity, competitiveness and sustainability of the entities on the markets, so as to maintain the favourable results in $80 \%$ ratio, but also to be overcome. Due to the elements composing the concept of Pareto's Law, but mainly to the practical use of the theoretical pattern of an ex-post nature, we consider it a true synapse within economics, in order to facilitate an well-functioning of the society and economy and to motivate a rising of productivity in all domains.
\end{abstract}

Keywords: managerial skills, income distribution, productivity, well-being, elite.

\section{Introduction}

In 1892, Vilfredo Federico Damaso PARETO (1848-1923) succeeded Léon Walras as chair of political economy at the Faculty of Law of the University of Lausanne and continued his research in the field of analytical economy, contributing above all to the emergence of the equilibrium theory and laying the foundations of the theory of economic efficiency. The latter theory essentially argues that voluntary exchanges between market participants, using price adjustment mechanisms, ultimately lead to an "optimal" economic situation. In other words, no subsequent transaction (or subsequent exchange) will make one participant "better off" while causing other participants to be worse off as a result. What could such a situation possibly lead to? An unacceptable distribution of personal income, as Pareto demonstrated that the match between effectiveness (i.e. the qualitative side of efficiency, according to Praxeology) and equity is not realistic. Increasing the wealth of nation is not enough to achieve higher levels of collective welfare. Therefore, created wealth ought to be distributed equitably rather than equally. Along these lines, V. Pareto explored the distribution of personal income (based on data available at the time, namely at the end of the $19^{\text {th }}$ century) and articulated the principle known in specialist literature as Pareto's Law:

The commonly known form of the Pareto law or principle is the $80-20$ ratio which states that: $20 \%$ of clients account for $80 \%$ of sales; $20 \%$ of components represent $80 \%$ of costs; $20 \%$ of the developed nations' control $80 \%$ of global wealth, etc.

Ex post approach: Pareto's Law (or the $80 / 20$ rule) states also that $80 \%$ of the objectives are achieved with $20 \%$ of means. In other words, it can be demonstrated, by empirical studies, for instance, that:

1. $80 \%$ of effects are due to $20 \%$ of causes;

2. $80 \%$ of decisions made in meetings are made in $20 \%$ of the meeting time;

3. $80 \%$ of revenues are generated by $20 \%$ of customers;

4. $80 \%$ of rejects are caused by $20 \%$ of manufacturing errors.

In essence, the central idea is that $80 \%$ of the consequences of economic actions (management actions included) are due only to the impact of $20 \%$ of the causes, which influence the system in focus. A further contribution to the development of this principle was provided by an American professor of Romanian descent, Joseph Juran, who introduced the principle under review in managerial theory and practice and it is the person who labelled these realities in economics, especially in management, as Pareto Law or 80/20 Rule. Nowadays, new insights come from the ideas and practical advice of Richard Koch, known as a successful, serial entrepreneur". In the knowledge-based economy, groups of researchers play a major 
role at microeconomic level, in order to establish those methods, procedures, to improve the theories and practices in economics, especially in management, even starting from the day-to-day activities and changes occurred in the natural or business environment.

When we are starting an action, we need resources, means, and tools, toward obtaining the proposed goals. We are convinced that it is mostly impossible to think a priori, exactly like in a chemical experiment, to introduce $20 \%$ of the resources, or $20 \%$ of the efforts in order to provide $80 \%$ of the results, or outputs. If, in an organization, overall objectives and individual ones are not always clearly defined, or are defined only at the whole organization and not at the level of the individual constituents, it is imperative that these objectives should be explained in an operational manner. Therefore, the management is often compared to a chain, whose quality does not depend on the overall quality of the strongest links, but the weakest links, which may thus entail to the collapse of the entire scaffold built. Therefore, the empirical data of application of Pareto Law, or Pareto Rule, are obtained only ex post, after the processes are finished and we can observe the 80/20 Rule is effectively implemented. Of course, we have to avoid some, traps" following the application of Pareto Law, such as the idea that $20 \%$ of the advertising fees lead to $80 \%$ of the clients, or to eliminate $80 \%$ of the inefficient results or actions does not mean that $20 \%$ of the people are guilty for this desirable aspect.

In addition, this assumption based on the early works of Juran, who pointed out that 20 percent of the defects causing 80 percent of the problems. Managers are focused on the better way for the firm (company, organization), in an original manner to organize the productive or services activities, to train the staff, to properly motivate it, in using fewer resources and to obtain, if it's possible, maximum results for the entity, for the individuals, even for the society (we speak about the implementation of management functions). The focalisation is to do right precisely and important things, tasks, jobs, with minimum efforts and factors involved, in order to obtain maximum of results for the individuals, or firms. Therefore, this economic assertion for managers and, especially for entrepreneurs, is to determine where the efforts have to be oriented and resources to be expend.

\section{Conclusion}

Exegetes of Pareto's work argue that, despite the underlying data of his research, based on the low taxation levels at the end of the $19^{\text {th }}$ century, the claim that the law applied only to high incomes and that it has not been strictly validated (Pareto contended that the number of income earners was more concentrated among lower income groups), Pareto's Law served as the starting point for in-depth research into economic inequality, dealing with a distribution of income aimed at the general welfare of human communities and not of separate individuals only. Equally relevant is the other side of Vilfredo Pareto's research activity, focusing on sociology, which completes and reinforces the theory mentioned above. I would recall that Pareto was regarded as the pre-eminent member of the Italian Elitist (my emphasis) School, build on theories developed by the leading Italian sociologist and political scientist Gaetano Mosca (1858-1941). In his considerations, Vilfredo Pareto relied on the notion of social heterogeneousness, by which he sought to demonstrate that all known societies involve separation and to a lesser extent an opposition between the mass of the governed and the limited number of individuals who dominate it, whom he called the elite.

This ultimately enabled, as we have seen, Richard Koch's transposition of the theory in the field of leadership. These factors have a decisive influence in the context of the organisation, by engaging and orienting actions in the direction intended by the management of companies (organisations) in order to achieve optimised results, through the concerted and focused efforts of individuals or of limited interest groups, considering that individuals (employees) = capital of the first degree. The ideas and mind power of individuals within an organization, corroborate with an adequate and flexible managerial frame, represent the engine for innovative processes, for superiority in competition with similar competitors and a recipe for making sound profit. People who work or manage, the entrepreneurs, using theirs knowledge, skills, abilities, capitals, become the main actors in developing Pareto 80/20 Rule, ensuring the well-being at micro and macroeconomic levels. Furthermore, in these days when media are a very important factor of the existence of individuals, firms, national economies, exactly the Pareto Rule is followed: $80 \%$ image and media exposure, with $20 \%$ of the involved resources.

But, above all, we consider that Pareto's Law has to be correctly used in practice, to become a powerful synapse within economics, making continuous improvements (innovation) in organizations and 
providing optimal solutions in these times of crisis and market failures, because as Pareto himself said, this economic and social synapse is,, in the nature of man", regards the endogenous power or forces of individuals, towards reaching theirs goals. Improving the quality of resources used, the renewed focus on the intensive exploitation of the factors of production (mainly, the labor) and the incorporation of the latest advanced TIC, there are jointly the factors which we consider vital for the sustainability and competitiveness of companies (organisations) on particular markets.

\section{References}

Cohen, A. (2011). The Law of the Vital Few, www.kajama.com (last accessing March 2011).

Certo, S. C. (2002). Management modern, Ed. Teora, București.

Facione, N. \& Facione, P. (2007). Thinking and Reasoning in Human Decision Making. The Method of Argument and Heuristic Analysis, The California Academic Press.

Kahneman, D. \& Tversky, A. (1979). Prospect Theory: An Analysis of Decision under Risk, in Econometrica XLVII.

Kerjean, A. (2002). Le manager leader, Ed. D’Organisation, Paris.

Koch, R. (2008). The 80/20 Principle. The Secret of Achieving More with Less, second edition, The Doubleday Publishing Group, New York.

Koch, R. (2005). The 80/20 Individual. How to Build on the 20\% of What You Do Best, The Doubleday Publishing Group, New York.

Parmenter, D. (2007). Pareto 80/20 Rule for Corporate Accountants, John Wiley \& Sons.

Trifu, A. (2006). Eseu privind panoptic de sinapse organice ale economiei (Essay regarding economics organic synapses), Ed. Performantica, Iasi.

Trifu, A. (2005). Gândirea economică în unitatea spațio-temporală (Economic Thoughts in Time and Space Unity), Ed. Performantica, Iasi.

Vroom, V. H. \& Jago, A. G. (1988). The new leadership: Managing participation in organizations, Englewood Cliffs, NJ: Prentice Hall. 